\title{
Crowd JLU: A Crowd-funding Platform for College Students
}

$$
\begin{aligned}
& \text { Jiaxin } \mathrm{Yu}^{1,} \text {, } \text {,Suya Zhao, }{ }^{1, b} \text {, Yuanyuan } \mathrm{Li}^{2, \mathrm{c}} \text {, Qiang Shen }{ }^{3, \mathrm{~d}} \text {, Hui Liu }{ }^{4, \mathrm{e}} \text { and Hao } \\
& X u^{2, f^{*}}
\end{aligned}
$$

${ }^{1}$ College of Software Engineering, Jilin University, Changchun 130012, China;

${ }^{2}$ College of Computer Science and Technology, Jilin University, Changchun 130012, China;

${ }^{3}$ College of Software Engineering, Jilin University, Changchun 130012, China;

${ }^{4}$ College of Earth Sciences, Jilin University, Changchun 130012, China;

ayujiaxin1117@163.com, b1123868039@qq.com, '645022087@qq.com,

d2495577286@qq.com, eliuhui_sunshine@sina.com,

fxuhao@jlu.edu.cn, “Corresponding Author

Keywords: Crow-funding, College Student, Website Design, Incubation

\begin{abstract}
College students lack certain guidance for their simple and immature enterprising pattern in miscellaneous market when they build business. Most of them needs like-minded and technical people. It is concluded that crowd-funding plays an important role in the entrepreneurship of undergraduates. Based on this, we propose a crowd-funding website specially aimed at servicing them to get fund support and find like-minded people. On the one hand, we assistant college students incubate their immature projects. On the other hand, we take full advantage of the data collected to achieve the transformation of scientific and technical achievements on the basis of their analysis. In a word, we are not incubating the projects but incubating the people who will lead the market in the future.
\end{abstract}

\section{Introduction}

Crowd-funding is a way of helping people of ideas to get fund to put their ideas into practice [1]. There are some famous and well-developed websites in America such as KickStarters and Crowdcube. Lots of supporters help experiencing product and service in early stage and then customers can make decisions whether they will take part in the project or not.

In China, Taobao crowd-funding, as the biggest electric commerce in China, takes full advantage of its abundant users. However, both of them are not such suitable for college students for their diversity. Considering the differences between America and China, this paper propose a platform to help college students find their suitable way to develop themselves. We provide service for college students such as fund, techs, and etc.

The rest of the paper is organized as follows: Section 2 introduces the motivation why we make such a website and the comparison between different crowd-funding websites. Section 3 presents solution to design our website. Section 4 is the conclusion of the platform.

\section{Motivation and Comparison}

Crowd-funding, which typically involves collecting small amounts of money from a large number of people, is a new label for an activity that has a rich history in many domains. For example, one of the largest crowd-funding projects to date is Eric Migicovsky's e-Paper Watch that integrates with an Android or iPhone-even though its original goal was $\$ 100,000$, the project eventually received contributions totaling over $\$ 10.2 \mathrm{M}$ in 37 days from over 65,000 backers [2].

But the same model in America is completely not suitable for China for the poor foundation in the country. First, we cannot deny the quality, creativity and team level of project is far from the leader. Second, it is hard for most platforms to realize the translation from online to offline [3]. Based on what is mentioned above, we decide to design such a website to service college students 
to achieve the translation from dream to practice.

Know yourself and know your enemy, you will win every war. We do some surveys at home and abroad and make a form as follows.

\begin{tabular}{|c|c|c|c|c|c|}
\hline $\begin{array}{l}\text { Features } \backslash \text { Web } \\
\text { s }\end{array}$ & KickStarters & Crowdcube & Crowdfunding & Taobao & AngelCrunch \\
\hline Specialists & $\begin{array}{l}\text { Any people aged } \\
\text { over eighteen are } \\
\text { allowed to } \\
\text { experience and } \\
\text { then decide } \\
\text { whether to join or } \\
\text { not }\end{array}$ & $\begin{array}{l}\text { Sell stocks } \\
\text { to attract } \\
\text { investors } \\
\text { and } \\
\text { enterprises }\end{array}$ & $\begin{array}{l}\text { Provide } \\
\text { fund-raising, } \\
\text { incubation and } \\
\text { running } \\
\text { assistant for } \\
\text { project } \\
\text { sponsors }\end{array}$ & $\begin{array}{l}\text { As the } \\
\text { biggest } \\
\text { E-business in } \\
\text { China, it has } \\
\text { the biggest } \\
\text { mass base }\end{array}$ & $\begin{array}{l}\text { High quality } \\
\text { and } \\
\text { experienced } \\
\text { investors, } \\
\text { ridiculous } \\
\text { check }\end{array}$ \\
\hline Direction & $\begin{array}{l}\text { Game occupies the } \\
\text { biggest share, then } \\
\text { famous at culture } \\
\text { and part ,especially } \\
\text { music projects }\end{array}$ & $\begin{array}{l}\text { Aimed at } \\
\text { retailing } \\
\text { and food } \\
\text { industry }\end{array}$ & $\begin{array}{l}\text { Cover an area } \\
\text { of art, design, } \\
\text { technology, } \\
\text { and public } \\
\text { welfare etc. }\end{array}$ & $\begin{array}{l}\text { Technology } \\
\text { equipment } \\
\text { accounts for } \\
\text { a proportion } \\
\text { of ninety }\end{array}$ & $\begin{array}{l}\text { Mainly aimed } \\
\text { at social } \\
\text { contact and } \\
\text { life service, } \\
\text { entertainment } \\
\text { next }\end{array}$ \\
\hline Model & $\begin{array}{l}\text { Commission based } \\
\text { crowd-funding }\end{array}$ & $\begin{array}{l}\text { Equality } \\
\text { based } \\
\text { crowd-fundi } \\
\text { ng }\end{array}$ & $\begin{array}{l}\text { Donation and } \\
\text { reward based } \\
\text { crowd-funding }\end{array}$ & $\begin{array}{l}\text { It is free of } \\
\text { charge and } \\
\text { aims at } \\
\text { enriching its } \\
\text { life-cycle }\end{array}$ & $\begin{array}{l}\text { It imports } \\
\text { membership } \\
\text { system instead } \\
\text { of common } \\
\text { people. }\end{array}$ \\
\hline
\end{tabular}

Table. 1 typical crowd-funding websites at home and abroad

After analyzing the form, we found that most websites aimed at multi-products and requested experienced people. As a result, that is not suitable for college students. They need certain guidance to perfect themselves. We believe that whether success or not, people build business today will do better in the future. In other words we are not incubating the projects but incubating the people who will lead the market in the future.

\section{Solution}

People do not buy what you sell they buy why you sell. As college students, how can we make our project success? First, from the point of idea, we suggest paying main attention to its quality. Because everything of the project has to be made public and bad quality is really a terrible thing. What's worse, the project lacks creativity. Second, do not emphasize the function of the project too much. Just as what Jobs said, most people do not simply support the project but your value and moral quality. Third, what is most important is that do not forget taking advantage of your resources as aundergraduate. Public outreach is at the forefront of crowd-funding proposals, and cultivating early connections with a wide audience often determines the success of individual funding drives [4]. We can speak out our project from our friends by social networks.

Next is the technical architecture of our website. We apply MVC (model view controller) to divide view layer and business layer to make it more logical and clearer. Thinkphp framework make the website powerful in extensibility. Database adopts MySQL.

A. Main implementation process of the system. It shows the action of the users after logging on the website, including weather he executes the action or not and what action he can make. 


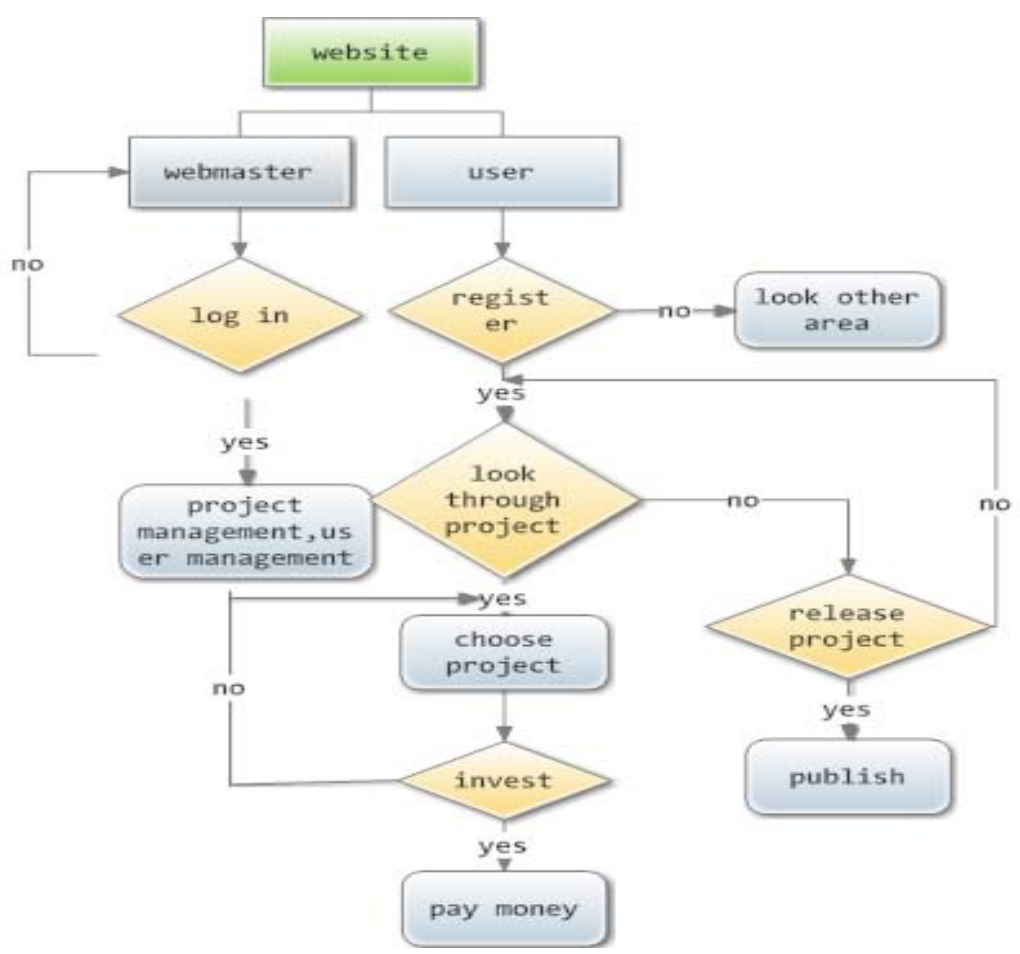

Fig. 1 the flow diagram of the website

B. Function diagram. It shows the details of the design, including what the website covers and what college students can achieve through our website.

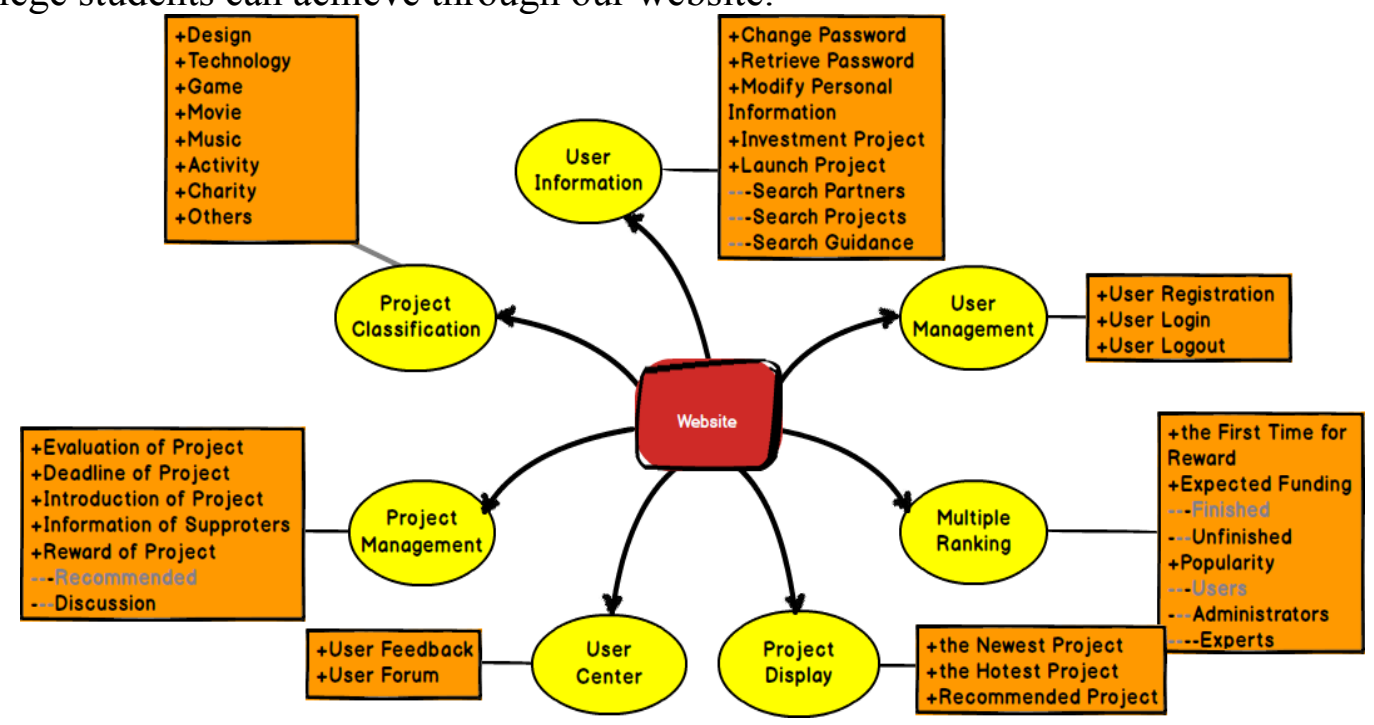

Fig.2 function diagram

When it comes to the time design for the project to collect enough money, on the one hand, the time should be long enough to form momentum, on the other hand, the time ought to be short enough to bring confidence to the supporters. Based on those, 30 days around is just suitable .

Also, the project package accounts for a large part during the whole process. It is reported that project with introduction video collects $14 \%$ more fund compared to the project without package [5]. Well, most Chinese do not have the ability of packaging the project. Five, updating information regularly not only promotes the connection with supporters deeply but make them to translate your project to other acquaintances. Finally, show your thanks to your supporters by e-mail, thus making supporters have the feeling of being taken seriously, which usually be ignored by Chinese people. What mentioned above seems insignificant but the key of the success of crowd-funding. 


\section{Conclusion}

We believe in that making crowd-funding widely available to creators with various levels of experience and sophistication can depend on a certain amount of hand-holding and guidance. As a result, we design such a website based on the parent situation of college students in China to help them transfer theory to practice [6]. The main attention of our design is not only to help college students achieve their projects but perfect themselves in the future. Besides, we take full advantage of the data collected from those projects to achieve the transformation of scientific and technical achievements on the basis of their analysis. To provide more professional service to initiators, we cooperate with the top guns in every fields. Up to now, the website is proved to be helpful and creative according to the website traffic and the feedback of college students.

\section{Acknowledgments}

The work is supported by the Education of Creation and Innovation of College Students Center in Jilin University, National Natural Science Foundation of China (No.61300147,No. 61472159), China Postdoctoral Science Foundation (No. 2014M551185), Electronic Commerce Engineering Laboratory Project of Jilin Province (2014N143), the Science and Technology Program of Changchun (No. 14GH014) and the Erasmus Mundus Swap and Transfer Project of the EU Commission.

\section{References}

[1] LoretaValaniene; SimaJegeleviiūte. Comparative Analysis of Value in the Context of Crowd-funding Platforms. International Conference on Applied Social Science (ICASS 2014) Volume 51, 2014

[2] Gobble,Mary Anne M.Everyone is a venture capitalist: The new age of crowd-funding. Research Technology Management. 2012

[3] HuanZhenglin, $\mathrm{Wu}$ Haowen. The Research of Releasing Equity Crowd-funding in China.Proceedings of the 6th (2014) International Conference on Financial Risk and Corporate Finance Management.2014

[4]Mollick E. The dynamics of crowd-funding: An exploratory study[J]. Journal of Business Venturing, 2014, 29(1): 1-16.

[5] Gerber E M, Hui J. Crowd-funding: Motivations and deterrents for participation[J]. ACM Transactions on Computer-Human Interaction (TOCHI), 2013, 20(6): 34.

[6] Bannerman S. Crowdfundingculture[J]. Wi Journal of Mobile Media Sound Moves, 2013, 7(1). 